\title{
Economics
}

HEI Working Paper No: 03/2004

\section{Macroeconomic volatility, debt dynamics, and sovereign interest rate spreads.}

\author{
Hans Genberg \\ Graduate Institute of International Studies \\ Astrit Sulstarova \\ Graduate Institute of International Studies
}

(c) The Authors.

All rights reserved. No part of this

paper may be reproduced without

the permission of the authors 


\title{
Macroeconomic volatility, debt dynamics, and sovereign interest rate spreads.
}

\author{
Hans Genberg ${ }^{1}$ and Astrit Sulstarova ${ }^{1}$
}

May, 2004

\begin{abstract}
While the relationship between volatility and risk is central to much of the financial literature it has not been incorporated systematically into assessment of sovereign debt sustainability. This paper attempts to fill this gap by studying how the probability distribution of sovereign debt to GDP ratios depends on the stochastic properties of underlying variables such as the real interest rate, the real growth rate, and the primary budget deficit. Due to the highly non-linear relationship between these variables and the debt ratios, Monte-Carlo simulations have to be used to estimate the probability distribution at different horizons. Using the right-hand tail of the distribution as a measure of the risk, we are able to show how the volatility of the underlying variables as well as potential interactions between them influences country risk.

Using estimates of volatility parameters of a sample of developed and emerging markets, we construct risk measures for each of them. We hypothesize that this risk measure should be positively correlated with the spread of sovereign bonds of the countries. Preliminary econometric tests suggest that this is indeed the case. Thus, while conventional analyses of the determinants of sovereign spreads have not focused on volatility dynamics, financial markets seem to have incorporated it in sovereign bond pricing.
\end{abstract}

JEL Classification: C15, F34

Keywords: Macroeconomic volatility, debt dynamics, sovereign spreads

\footnotetext{
1 Graduate Institute for International Studies, Pavillon Rigot, Avenue de la Paix 11a, CH-1202, Geneva, Switzerland. Email: genberg@hei.unige.ch, and sulstaa7@ hei.unige.ch.

"This project has been carried out within the NCCR Finrisk project "Macro Risk, Systemic Risk and International Finance. The NCCR FINRISK is a research program supported by the Swiss National Science Foundation."
} 


\section{Introduction.}

The value of bonds issued by emerging markets has grown enormously over the course of the last 20 years, reaching 3.7 trillion USD $^{2}$ in 2004 and becoming one of the primary devices for satisfying emerging market financing needs. With improving economic conditions and increased globalization of financial markets, many emerging markets have better access to capital markets and consequently have accumulated more debt to finance their economic activities. Despite this increased importance of sovereign debt, there are relatively few studies that have tried to determine the pricing behaviour of investors for this asset class.

The existing literature has examined emerging bond market spreads empirically as a function of different fundamentals. ${ }^{3}$ Standard macroeconomic variables, such as real GDP growth, various debt ratios, international reserves, and international interest rates have been found to be significant. Although the theoretical reasons for including these variables are not always spelled out, the underlying notion is that they are all related to the probability of default.

In this paper we argue that volatility of macroeconomic variables underlying the evolution of sovereign debt plays a crucial role in explaining bond spreads. Although the finance literature regularly emphasizes volatility as the crucial variable for pricing of financial assets, to our knowledge there are no studies that have introduced volatility of macroeconomic variables as explanations of sovereign bond spreads. ${ }^{4}$

In theory there are two possible influences of volatility on bond spreads. ${ }^{5}$ One says higher volatility increases the demand for international borrowing to help smooth consumption (Eaton and Gersovitz 1981), whereas another argues that volatility induces higher default risk, reduces the debt/GDP threshold (Catao and Kapur (2004)), and thereby increases the interest rate. Our empirical work supports the second view that volatility helps explain a significant portion of sovereign spread.

The link between macroeconomic indicators such as real growth rates, debt ratios, etc. and sovereign bond spreads is often rationalized with reference to the literature on debt sustainability. This literature can be divided into two strands. The first, which looks at the asymptotic properties of the evolution of debt, is represented by the seminal paper of Hamilton and Flavin (1986) followed by Trehan and Walsh(1988), Kremers(1989), Hakkio and Rush $(1991)$, Wilcox $(1989,1991)$ and Ahmed and Rogers(1995) among others. The general conclusion to emerge is that the debt/fiscal policy is sustainable if the government budget constraint holds in present value terms meaning that the current debt should be offset by the sum of expected future discounted primary budget surpluses. Most of these papers (Wilcox (1989) is an exception) assume a constant real interest rate which may not be a good characterization of the data. In addition they use unit root and/or cointegration based tests which require long time series (say 50-100 annual

\footnotetext{
${ }^{2}$ Moodys estimate

${ }^{3}$ Edwards (1986), Eichengreen and Mody (1998), Cline and Barnes (1997).

${ }^{4}$ Volatility parameters have been introduced in models estimating the probability of default. See, for example, Catao and Kapur (2004), Eaton and Gersovitz (1981), and Peter (2002).

${ }^{5}$ See Catao et al. (2004) for an analysis of the theoretical link between volatility of macroeconomic variables and the probability of default.
} 
observations). For most emerging markets such data series are either not available or suffer from structural breaks.

The second strand of the debt sustainability literature is well represented by IMF (2002), Goldstein (2003), and Goldfajn (2002), among others. This literature is often policy focused and typically investigates the implications of alternative macroeconomic scenarios for the expected path of internal or external debt.

Particularly interesting in this context is the stress-testing approach in IMF (2002), which comes close to what we propose in this paper. Our basic hypothesis is that the riskyness of a sovereign bond depends not only on the expected future path of the debt ratio, but also on its entire probability distribution, particularly its right-hand tail. ${ }^{6}$ Even if the expected (i.e. the most probable) time path of a country's debt looks sustainable, it is possible that some realizations of the underlying variables will bring it to levels that are considered for creditors to be 'too high'. The likelihood of such realizations depends on the volatilities of the underlying determinants of the debt ratio, and hence we hypothesize that these volatilities will be important for the size of sovereign interest rate spreads.

In the next section of the paper we develop a framework for identifying the parameters determining the shape of the probability distribution of the debt/GDP ratio of a government. Sensitivity tests are carried out to illustrate the relative importance of different sources of volatility and of certain types of interactions between the fundamental determinants of the debt ratio. We propose an aggregate measure of riskyness and use it in section III of the paper to test the hypothesis that sovereign spreads depend significantly on the volatility of the underlying macroeconomic fundamentals. The results we obtain from a panel regression study of ten countries over the period 1997:4 to 2000:3 are consistent with our hypothesis.

\section{A framework for Estimating the Distribution of the Debt/GDP Ratio.}

\section{II.1 The simple dynamics of debt/GDP}

The Government Flow Budget Constraint can be expressed as: ${ }^{7}$

$$
G_{t}-T_{t}+i_{t} B_{t-1}^{d}+i_{t}^{*} E_{t} B_{t-1}^{*}=\Delta L_{t}^{g}+\Delta B_{t}^{d}+E_{t} \Delta B_{t}^{*}
$$

where $\quad G \quad$ : public spending on good and services;

$T \quad$ : total revenue;

$B^{d} \quad$ : end of the period stock ofdomestic public debt;

$B^{*} \quad$ : end of the period stock of foreign currency denominated debt;

$i_{t} \quad$ : interest rate on one period domestic debt;

\footnotetext{
${ }^{6}$ IMF (2003) has mentioned the approach we are suggesting for assessing sustainability, but they don't use it as mainstay in their sustainability analysis and they don't develop the idea in detail. Barnhill and Kopits (2003) use the balance sheet approach test about fiscal sustainability under uncertainty through producing density distribution.

${ }^{7}$ This follows Agenor(2001)
} 


$$
\begin{array}{ll}
i_{t}^{*} & : \text { interest rate on one period foreign currency denominated debt; } \\
E_{t} & : \text { nominal exchange rate; } \\
L_{g} & : \text { nominal stock of credit obtained by the fiscal authority from the } \\
& \text { Central Bank; }
\end{array}
$$

The identity (1) simply states that the government's spending on goods and services net of taxes (conventional fiscal balance) must be financed either by issuing domestic bonds, borrowing abroad or borrowing from Central Bank. If we denote primary fiscal balance as $D_{t}=G_{t}-T_{t}$ and we add and subtract $E \Delta R^{*}$ (the foreign exchange reserves expressed in domestic currency) we get:

$$
D_{t}+i_{t} B_{t-1}^{d}+i_{t}^{*} E B_{t-1}^{*}=\left(\Delta L_{t}^{g}+E \Delta R_{t}^{*}\right)+\Delta B_{t}^{d}+E\left(\Delta B_{t}^{*}-\Delta R_{t}^{*}\right)
$$

From the Balance Sheet of the Central Bank we have

$$
L_{g}+E R^{*}=M+N W^{c b}
$$

where $M$ is monetary base and $N W$ is net worth of Central Bank.

Then

$$
\Delta L^{g}+E \Delta R^{*}=\Delta M+\Delta N W^{c b}
$$

Abstracting from operational costs, the change of net worth is equal with interest earning from official reserves.

$$
\Delta M_{t}=\Delta L_{g}+E_{t} \Delta R_{t}^{*}-i_{t}^{*} E_{t} R_{t-1}^{*}
$$

and using (2) we obtain

$$
D_{t}+i_{t} B_{t-1}^{d}+i_{t}^{*} E_{t}\left(B_{t-1}^{*}-R_{t-1}^{*}\right)=\Delta B_{t}^{d}+E_{t} \Delta\left(B_{t}^{*}-R_{t}^{*}\right)+\Delta M_{t}
$$

Given that base money is a liability of the public sector, net foreign assets held by the Central Bank must be subtracted from the government's foreign debt to calculate the net external liabilities of the public sector. Let $B_{t-1}^{*}-R_{t-1}^{*}=B_{t-1}^{*}$ (or assuming that reserves are equal with zero).

From (6) we get:

$$
B_{t}^{d}+E_{t} B_{t}^{*}=\left(1+i_{t}\right) B_{t-1}^{d}+\left(1+i_{t}^{*}\right) E_{t} B_{t-1}^{*}+D_{t}-\Delta M_{t}
$$

and dividing (7) by the price level and the GDP we have: 


$$
\frac{B_{t}^{d}}{P_{t} Y_{t}}+\frac{E_{t} B_{t}^{*}}{P_{t} Y_{t}}=\left(1+i_{t}\right) \frac{B_{t-1}^{d}}{P_{t-1} Y_{t-1}} \frac{P_{t-1}}{P_{t}} \frac{Y_{t-1}}{Y_{t}}+\left(1+i_{t}^{*}\right) \frac{E_{t}}{E_{t-1}} \frac{E_{t-1} B_{t-1}^{*}}{P_{t-1} Y_{t-1}} \frac{P_{t-1}}{P_{t}} \frac{Y_{t-1}}{Y_{t}}+\frac{D_{t}}{P_{t} Y_{t}}-\frac{\Delta M_{t}}{P_{t} Y_{t}}
$$

or

$$
b_{t}^{d}+b_{t}^{*}=\frac{\left(1+i_{t}\right)}{\left(1+g_{t}\right)\left(1+\pi_{t}\right)} b_{t-1}^{d}+\frac{\left(1+i_{t}^{*}\right)\left(1+\xi_{t}\right)}{\left(1+g_{t}\right)\left(1+\pi_{t}\right)} b_{t-1}^{*}+d_{t}-s_{t}
$$

where $\xi=\frac{E_{t}}{E_{t-1}}-1$ is the rate of change of the average nominal exchange rate, and $s_{t}$ is the ratio of seignorage to GDP. By letting $b_{t}=b_{t}^{d}+b_{t}^{*}$ and defining the real interest rate on domestic and external debt expressed in domestic currency as $r_{t}^{d}=\frac{\left(1+i_{t}\right)}{\left(1+\pi_{t}\right)}-1$ and $r_{t}^{*}=\frac{\left(1+i_{t}^{*}\right)\left(1+\xi_{t}\right)}{\left(1+\pi_{t}\right)}-1$ respectively we can write the evolution of public debt is as

$$
b_{t}=\frac{\left(1+r_{t}\right)}{\left(1+g_{t}\right)} \cdot b_{t-1}+d_{t}-s_{t}
$$

where the weighted real interest rate relevant for the total debt is defined as

$$
r_{t}=r_{t}^{d} \frac{b_{t-1}^{d}}{b_{t-1}}+r_{t}^{*} \frac{b_{t-1}^{*}}{b_{t-1}}
$$

Equation (10) will be the main equation in our framework as it has been in previous studies. The fiscal sustainability approach iterates it frward and test empirically if the government budget constraint holds in present value terms meaning that the current debt should be offset by the sum of expected future discounted primary budget surpluses. These empirical tests are thus carried out purely in terms of asymptotic properties of the debt ratio.

The scenario approach hypothesizes a limited number of scenarios for $r_{t}, g_{t}, d_{t}$, and $s_{t}$, and uses these to calculate the implied paths for the debt ratio. We look at the entire distribution of future debt ratios as a function of the nature of the stochastic processes governing these same variables. ${ }^{8}$

\section{2 The probability distribution of the debt ratio.}

In view of the non- linearity of equation (10) and the potentially complex interrelations between the variables that appear in it, we will calculate the probability distribution of the debt ratios at various future points in time by means of Monte Carlo

\footnotetext{
${ }^{8}$ In what follows we do not take into account seignorage as a source of financing.
} 
simulations. Our approach is inspired by the Value at Risk (VaR) methodology in financial risk management. There the question is 'What is the size of the loss on a portfolio of assets that an investor can incur under particularly unfavorable realizations of the individual returns?' Unfavorable realizations are those that fall in the tail of the assumed or estimated joint distributions of the returns. We ask the analogous question, 'What will be the size of the debt to GDP ratio under particularly unfavorable, but still possible, realizations of growth, interest rates, and primary deficits?'

For ease of presentation we will focus our presentation on the $95^{\text {th }}$ percentile of the distribution of the debt ratio. We will thus present graphs that take the form of a fan chart in which the upper $95^{\text {th }}$ percentile of the debt ratio will be plotted against the horizon of the forecast, as in Figure 1. The interpretation of such a figure is as follows. Suppose that $r_{t}, g_{t}$, and $d_{t}$ were constant over time. Then equation (10) would imply a particular steady state debt ratio. ${ }^{9}$ With stochastic fundamentals however, the outcome for the debt ratio is of course also stochastic, and with a strictly positive probability it will exceed a critical value where creditors might stop lending, at which point default could occur. ${ }^{10}$ This is illustrated in the figure by the hypothetical $95^{\text {th }}$ percentile of the debt ratio crossing the critical value of the debt ratio. In other words, even if the most likely future macroeconomic scenario in a country implies a sustainable debt ratio, unfavorable shocks may push it beyond the point where a debt crisis will ensue. The parameters that determine the likelihood of this happening are those that govern the joint stochastic process of the fundamentals.

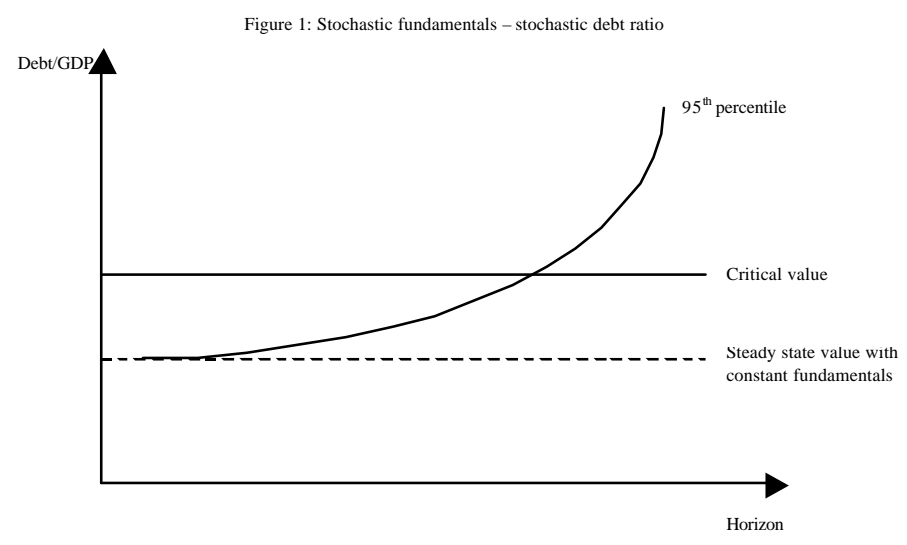

\section{II.3 Modeling the 'fundamentals'.}

In selecting the model for the fundamental variables we take into consideration two main factors: (i) the processes governing real GDP growth, real interest rate and primary deficit are typically persistent, and (ii) there are likely to be interactions between interest rates, growth, and primary deficits. We incorporate persistence by modeling the variables as $1^{\mathrm{st}}$ order autoregressive processes, and we include interrelations between the variables that we deem to be most relevant in our context. Specifically, we hypothesize that real growth depends negatively on the real rate of interest rate, that higher debt

\footnotetext{
${ }^{9}$ We assume that the conditions for stability of the difference equations are met.

${ }^{10} \mathrm{We}$ do not discuss the determinants of this critical value here. Its existence is however implied by the literature on credit rationing.
} 
increases the real interest rate due to the emergence of a risk premium, and that growth may influence the primary deficit. ${ }^{11}$ This leads us to the specification given in (11).

$$
\begin{aligned}
& g_{t}=\bar{g}+\rho_{g} *\left(g_{t-1}-\bar{g}\right)-\rho_{g r} *\left(r_{t-1}-\bar{r}\right)+u_{1 t} \\
& r_{t}=\bar{r}+\rho_{r} *\left(r_{t-1}-\bar{r}\right)+\rho_{r b} *\left(b_{t-1}-\bar{b}\right)+u_{2 t} \\
& d_{t}=\bar{d}+\rho_{d} *\left(d_{t-1}-\bar{d}\right) \pm \rho_{d g} *\left(g_{t-1}-\bar{g}\right)+u_{3 t}
\end{aligned}
$$

The shocks are assumed to be normally distributed according to

$$
\begin{aligned}
& u_{1, t} \sim N\left(0, s_{1} \cdot\left(\frac{\bar{g}}{2}\right)^{2}\right) \\
& u_{2, t} \sim N\left(0, s_{2} \cdot\left(\frac{\bar{r}}{2}\right)^{2}\right) \\
& u_{3, t} \sim N\left(0, s_{3} \cdot\left(\frac{\bar{d}}{2}\right)^{2}\right)
\end{aligned}
$$

where $\bar{g}, \bar{r}, \bar{d}$ are the steady state values and $s_{1}, s_{2}, s_{3}$ are positive constants.

\section{II.3.1 Calibration}

For our first illustration of how shocks, persistence, interdependence, and nonlinearities interact to generate a distribution of possible debt ratios we have chosen parameters given in Table 1 . The steady state values of the real growth rate, real interest rate, and the primary deficit (as a percent of GDP) are 3\%, 2\% and $0.5 \%$ respectively expressed as annual rates ${ }^{12}$. These values imply a steady state value of the debt ratio of $50 \%$. The coefficients on the interaction terms imply

- that an increase in the real interest rate of one percentage point (on an annual basis) will decrease real growth by .17 percentage points in the subsequent quarter

- that an increase in the debt ratio by 10 percentage points will increase the real interest rate by .10 percentage points in the next quarter

- that an change in the real growth rate by 1 percentage point will change the primary deficit by one quarter of one percentage points

\footnotetext{
11 The empirical literature does stress the relation between fiscal policy and business cycle but it does not give a clear answer whether the effect is positive or negative. Some empirical work, for example Gavin and Perotti (1997), has shown procyclicality in fiscal policy in Latin American countries while the evidence is that the fiscal policy is counter cyclical in OECD countries .

${ }^{12}$ Note that the figures in the table are expressed as quarterly rates.
} 
The standard deviations of the shocks to the real interest rate and the primary deficit are assumed to be of the same size as the corresponding means, while for the growth rate it is equal to two thirds of the mean. These choices are consistent with empirical results we obtain in section III of the paper.

Table 1. Parameters used in the Monte Carlo simulations.

\begin{tabular}{|c|c|c|c|c|}
\hline Parameters & debt & $\begin{array}{l}\text { real growth rate } \\
\text { (quarterly) }\end{array}$ & real interest rate & primary deficit \\
\hline Steady state level & $\bar{b}=0.5$ & $\bar{g}=0.0075$ & $\bar{r}=0.005$ & $\bar{d}=0.00125$ \\
\hline Autoregresive coefficients & & $\rho_{g}=0.95$ & $\rho_{r}=0.95$ & $\rho_{d}=0.95$ \\
\hline Interaction coefficients & & $\rho_{g r}=0.17$ & $\rho_{r b}=0.01$ & $\rho_{d g}=0.25$ \\
\hline Standard deviations & & $\delta(g)=0.00498$ & $o ́(r)=0.005$ & $o ́(d)=0.00125$ \\
\hline
\end{tabular}

Using the model described in (11), the parameters in Table 1, and equation (10) we can generate density forecasts of the debt ratio at all future horizons. Figure 2 presents the results for a horizon of 16 quarters based on 100000 draws from the distributions of the shocks to the growth rate, real interest rate and the primary deficit. Two remarks are warranted on the basis of this figure. First, with non-trivial probability it appears that the debt ratio can exceed $100 \%$ even in a setup where a non-stochastic scenario would predict a ratio of $50 \%$. Second, there is significant skewness in the distribution function which comes from the non-linearity of equation (10). This implies that it may be misleading to work with linearized versions of that equation when we consider explicitly the stochastic nature of the underlying variables.

Figure 2.

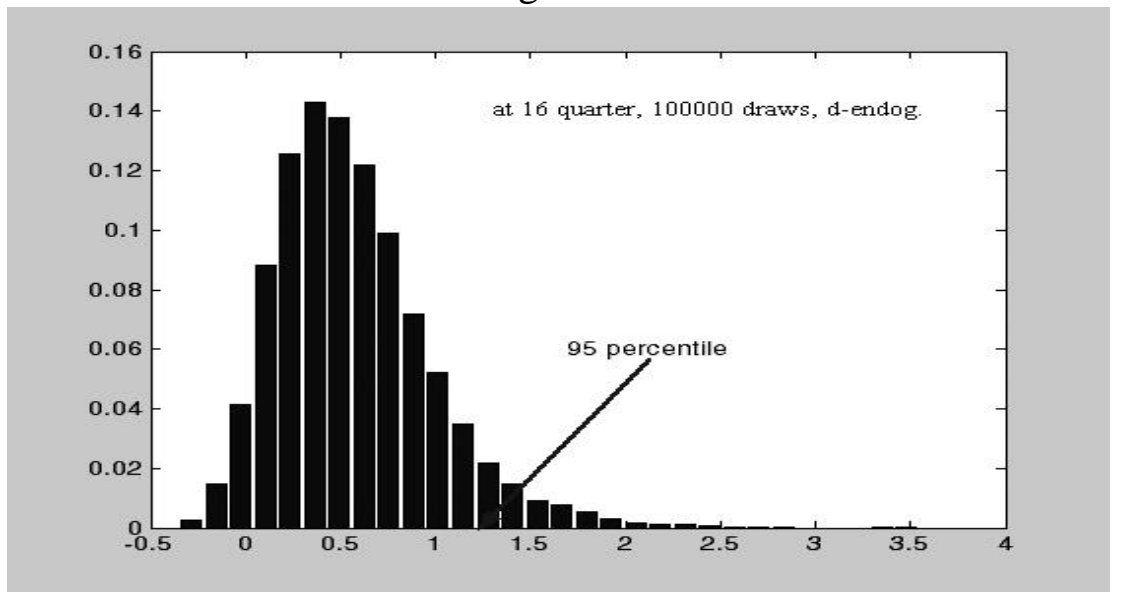

The $95^{\text {th }}$ percentile of debt to GDP ratio as a function of the simulation horizon is given in Figure 3. We see that after 16 quarters there is $5 \%$ probability that the debt ratio could be above $130 \%$ for this economy where the non-stochastic steady state value is $50 \%$. 
While our framework produces a density forecast, it leaves open the question of threshold level of debt to GDP. Our contention is that if a country's debt level goes beyond a critical level, its access to further financing may be seriously curtailed potentially to the point of provoking a crises. Research has not yet progressed to the point of being able to identify these danger levels empirically however. Part of the problem is that the critical level is country specific and related to a number of institutional and structural factors other than those considered here. Reinhart et. al. (2003), for example, claim that history matters and sometimes the external debt threshold could be as low as $15 \%$ while in other cases it would be much higher. In another study Detragiache and Spilimbergo (2001) found a threshold of $44 \%$ of external debt to GDP above which there a 20 percent probability of sovereign debt crises. In any event, ceteris paribus, countries for which the distribution of future debt levels is more skewed to the right should be considered as more risky debtors than countries for which the upper tail of the debt distribution contains a smaller mass. We now turn to an analysis of how sensitive the distribution is to the nature of the processes defining the fundamentals.

Figure 3.

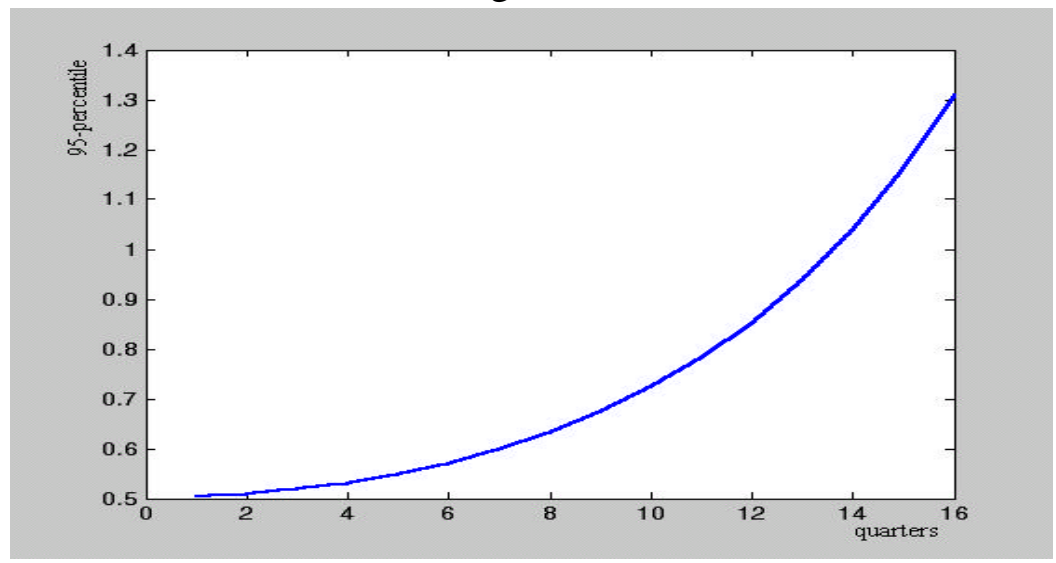

\section{II.3.2 Sensitivity analysis}

We investigate the sensitivity of the debt ratio to changes in three groups of parameters: the standard deviation of the shocks, autoregressive parameters and the interactive parameters. In each case when we change a parameter in (11) we adjust $\bar{d}$ so as to make the non-stochastic steady-state value of b equal to $50 \%$.

Figures 4 and 5 illustrate the effects of changing the standard deviation of the shocks and the interaction parameters respectively. In each case we multiply the baseline values by factors ranging from 0.6 to 1.5 in steps of 0.1 . Hence the values of the $95^{\text {th }}$ percentile when the multiplicative factor is 1 are exactly those that are given in Figure 3. We note that the distribution of $b$ is quite insensitive to variations in the volatility of the primary deficit, whereas changes in the volatility of both $r$ and $g$ can have substantial impacts. The sensitivity to the interaction parameters is largest for $\rho_{\mathrm{dg}}$ and $\rho_{\mathrm{gr}}$, the effect of growth on the primary deficit and the effect of the interest rate on growth, respectively. 
Figure 4: Sensitivity of the $95^{\text {th }}$ percentile of $b$ to changes in the standard deviations of the shocks.

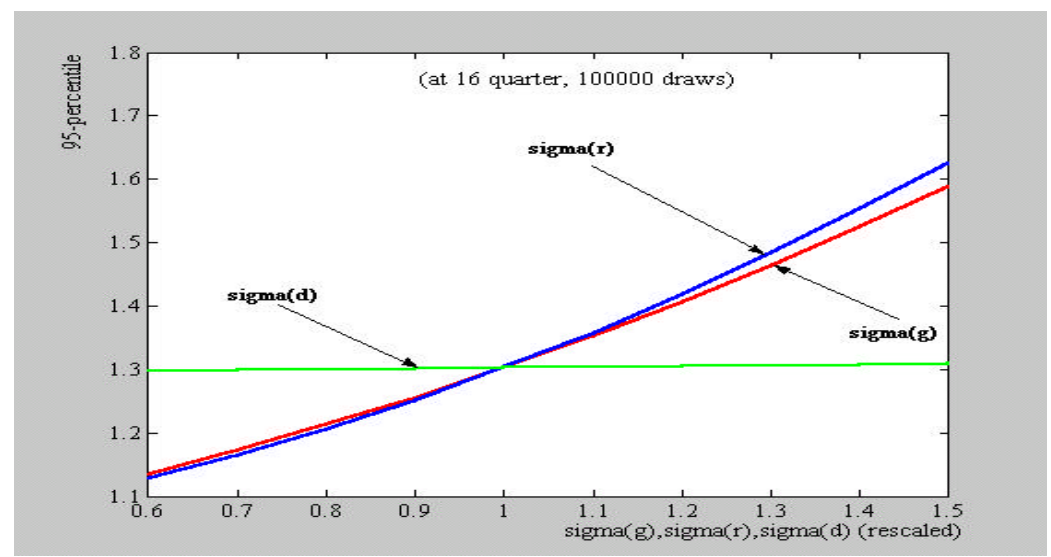

Figure 5: Sensitivity of the $95^{\text {th }}$ percentile of $\mathrm{b}$ to changes in the interaction parameters.

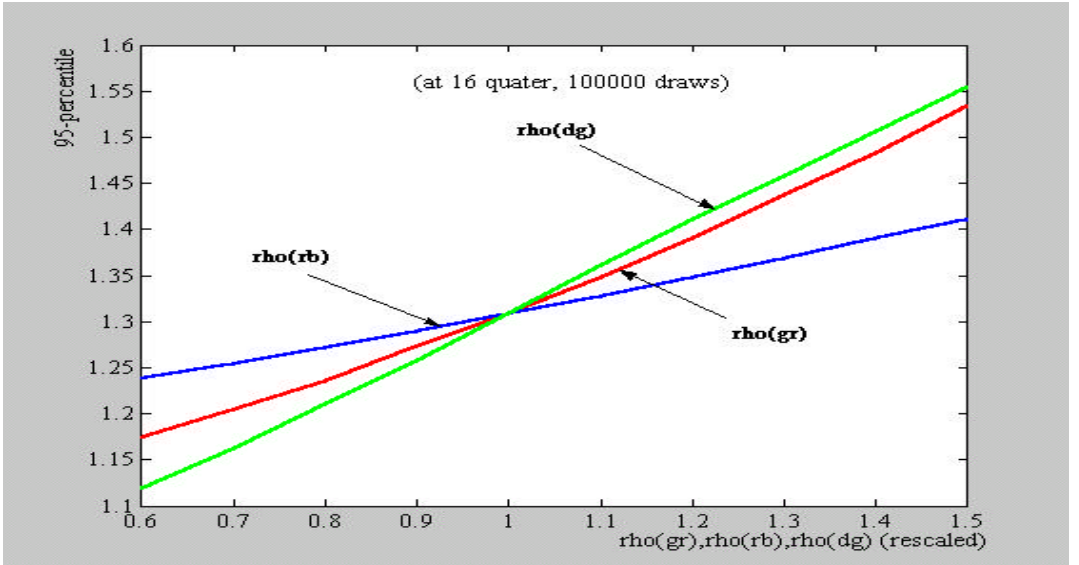

Figure 6 shows not surprisingly that increases in the autoregressive parameters imply a spreading out of the distribution of the debt ratio. Once again, the sensitivity is least pronounced in the case of the autoregressive parameter of the primary deficit, the reason being that it enters equation (10) linearly. 
Figure 6: Sensitivity of the $95^{\text {th }}$ percentile of $\mathrm{b}$ to changes in the autoregressive parameters.

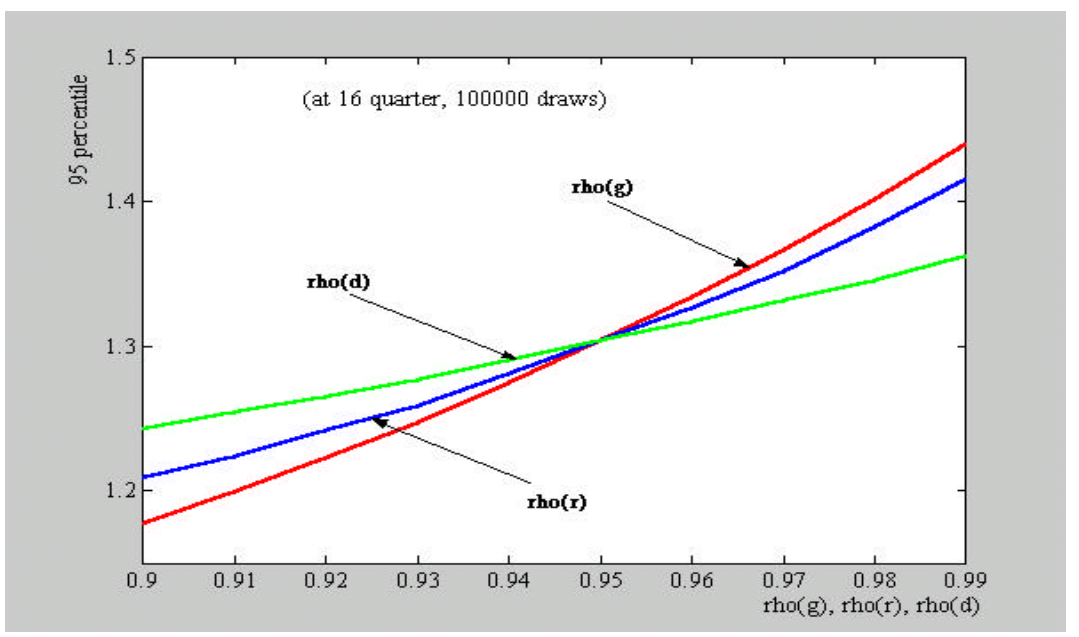

Finally, in Figure 7 we illustrate the importance of the relationship between the real interest rate and the real growth rate. Recall that in the baseline simulation the steady state value of the former was $2 \%$ and the latter 3\%. In Figure 7 this relationship is reversed so that the real interest rate is greater than the growth rate. As mentioned above, we adjust $\bar{d}$ at the same time from a deficit to a surplus such that the steady state value of $\mathrm{b}$ remains at $50 \%$. The result shows that making the interest rate greater than the growth rate makes the economy riskier even when the primary deficit is adjusted so as to make the government solvent in a steady state expected value sense.

Figure 7: Sensitivity of the $95^{\text {th }}$ percentile of $\mathrm{b}$ to the relationship between $\bar{r}$ and $\bar{g}$

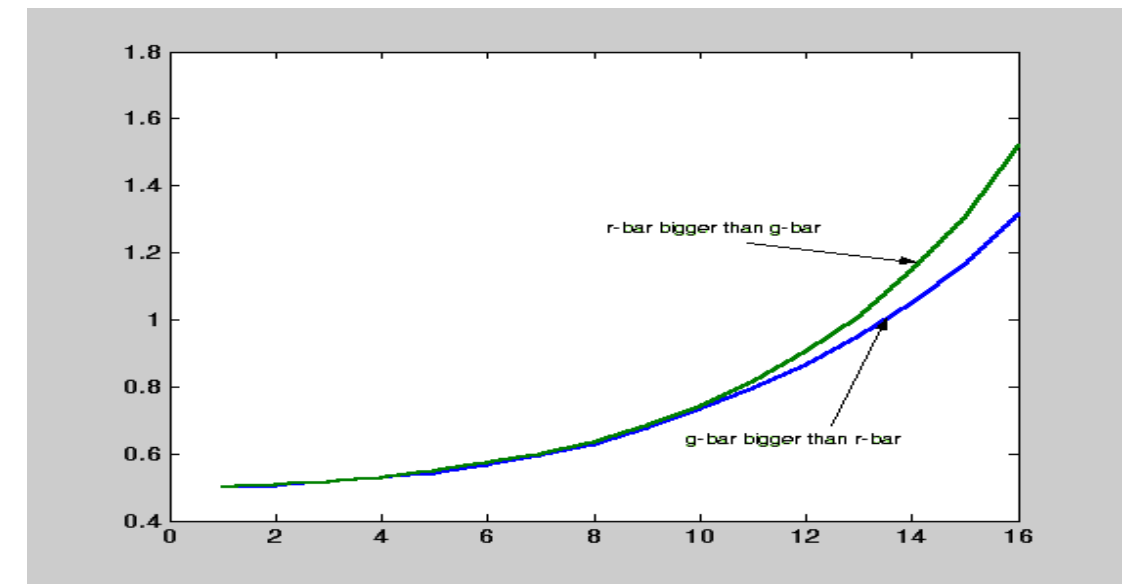




\section{II.3.3. A vulnerability index.}

The sensitivity of debt ratios to volatility and interaction parameters suggests interest rate spreads on sovereign bonds, or other measures of country risk, should depend on these parameters in a well-defined way. In order to limit the number of parameters to consider, we argue that the $95^{\text {th }}$ percentile of the simulated distribution of the debt/GDP ratio can be viewed as an aggregate 'vulnerability index'. This index effectively combines the whole set of volatility and interaction parameters using weights that are appropriate from the point of view of their importance in determining potential debt outcomes. In the next section we estimate vulnerability indices for ten sovereign debtors and include them in equations explaining interest rate spreads.

\section{An econometric model of interest spreads on sovereign debt.}

The previous literature on the determinants of interest rate spreads have used one of three different measures as the dependent variable in the analysis: (i) primary yields [Edwards(1986), Kamin and Kleist (1999), Min(1998)], (ii) primary yields corrected for selection bias [Eichengreen and Mody (1998)], or (iii) secondary market spreads [Goldman and Sachs(2000), DellAriccia, Goede and Zettelmeyer (2002), Ferruci(2003)]. Given the data available for constructing the risk variable we follow Cline and Barnes (1997) and use yields on Eurobonds of ten emerging and developed countries. Table 2 lists the countries and the bonds together with summary statistics on the spreads.

Table 2: Bond yields used in the empirical analysis.

\begin{tabular}{lccccc}
\hline Country & Issue year & Maturity & Coupon & Mean & Spread over US treasury \\
Argentina & 1993 & 2003 & $83 / 8$ & 463 & Std. Deviation \\
Belgium & 1993 & 2003 & $51 / 2$ & 49 & 130 \\
Brazil & 1993 & 2003 & $83 / 4$ & 441 & 155 \\
Indonesia & 1996 & 2006 & $73 / 4$ & 770 & 359 \\
Ireland & 1993 & 2003 & $67 / 8$ & 54 & 17 \\
Italy & 1993 & 2003 & $65 / 8$ & 53 & 21 \\
Mexico & 1990 & 2019 & $61 / 4$ & 148 & 16 \\
Sweden & 1998 & 2003 & 6 & 69 & 172 \\
Thailand & 1997 & 2007 & $73 / 4$ & 287 & 143 \\
Turkey & 1997 & 2007 & $10 \%$ & 525 & \\
\hline
\end{tabular}

The specification of the equation for the interest rate spread is

$$
\begin{aligned}
& s_{i, t}=\alpha_{0}+\alpha_{1} \operatorname{Risk}_{i, t-1}+\alpha_{2} \frac{D_{i, t-1}}{X_{i, t-1}}+\alpha_{3} \frac{R_{i t-1}}{M_{i, t-1}}+\alpha_{4} \frac{C A_{i t-1}}{X_{i, t}}+\alpha_{5} \frac{F_{i t-1}}{Y_{i, t-1}}+\alpha_{6} i_{i, t-1}+ \\
& +\alpha_{7} D_{I, i}+\alpha_{8} D_{B, i}+\alpha_{9} D_{R, i}+\alpha_{10} \sigma(g)_{i, t-1}
\end{aligned}
$$

where the subscript $i$ refers to countries in the sample and the variables are defined by 
$s \quad$ - the spread;

Risk - our 'vulnerability' measure discussed in the previous section

$\frac{D}{X} \quad$ - external debt to export;

$\frac{R}{M} \quad$ - reserve to import;

$\frac{C A}{X} \quad$ - current account balance to export;

$\frac{F}{Y} \quad$ - central government fiscal balance to GDP;

$i_{t} \quad$ - nominal interest rate on US 10-year treasury bonds.

$D_{I} \quad$ - dummy for industrial country;

$D_{B} \quad$ - dummy if the country has been involved in debt forgiveness under the Brady Plan;

$D_{R} \quad$-reputation dummy, is 1 when you have defaulted on your debt at least once in last 20 years;

$\sigma(g)$ - the volatility of the real growth rate

External debt to export or external debt to GDP is part of every empirical study in the literature and is found to be significantly positive. The interpretation is that the variable captures the country's capacity to service its debt. The size of international reserves helps to cushion temporary fluctuations in the balance of payments and reduces the risk of debt-service difficulties. It is therefore expected to have a negative influence on the spread. Conversely the higher the current account deficit the greater is the need for external finance and the higher the interest rate spread. The fiscal balance, measured as the difference between total revenues and total expenditure including interest payment on outstanding debt, is expected to have a negative relationship with spreads since higher fiscal balance means higher capacity to service debt and higher possibility to reduce the debt stock.

International interest rates are common determinants of the bonds spreads. The literature suggest that spreads are negatively related to short term rates since they increase the cost of borrowing, while they are positively related to long-term rates. As our sample includes both developed and emerging market countries a dummy variable is included in the equation to control for differences between them that are not captured by the other variables. Other dummy variables are included to capture potential effects of restructuring programs and countries' default histories. ${ }^{13}$

To the standard specification we add our risk variable which we expect to have a positive influence on the spread since it is related to the probability that the debt ratio of the country might become very large as a result of particularly unfavourable shocks to the underlying variables. To test whether the volatility of output growth is sufficient to capture the effect of risk as in Catao, et.al., we also add the standard deviation of output growth to the specification. ${ }^{14}$

${ }^{13}$ Data are taken from Detraighe \& Spilimbergo (2001);

${ }^{14}$ In fact Catao et al.(2004) use output volatility rather output growth volatility; 


\section{III.1 Description and construction of the risk variable}

Recall equation (10) which showed that the debt/GDP ratio, $b_{t}$, evolves according to

$b_{t}=\frac{\left(1+r_{t}\right)}{\left(1+g_{t}\right)} \cdot b_{t-1}+d_{t}$

where $r$ is the real rate of interest, $g$ is the real growth rate and, $d$ is the primary budget deficit. ${ }^{15}$ As explained in section II our risk measure is based on the $95^{\text {th }}$ percentile of the distribution of the future value of the debt ratio, where the distribution is based on MonteCarlo simulations of equation (13) together with estimated stochastic processes for fundamental variables $r, g$, and $d$.

III.1.1 Estimation of the stochastic processes for the fundamentals.

The countries included in the empirical analysis were Argentina, Belgium, Brazil, Indonesia, Ireland, Italy, Mexico, Sweden, Thailand and Turkey, and the sample period is dependent on the availability of the data. ${ }^{16}$

\section{Real GDP growth rate}

Following the specification in section II we assumed that real GDP growth follows a $1^{\text {st }}$ order autoregressive process with an additional influence from the real interest rate.

$$
g_{t}=\bar{g}+\rho_{g} g_{t-1}+\rho_{g r} r_{t-1}+u_{g t}
$$

The estimation results are given in Table 3. Most of the variables (lagged growth as well as the interactive term) are significant at the $1 \%$ level. Generally speaking the emerging markets in the sample have a higher mean growth rate than the high-income countries. As is expected, the average volatility of emerging markets is also higher. Within the emerging market group Argentina and Mexico stand out as having particularly volatile GDP growth rates.

\footnotetext{
${ }^{15}$ We do not consider seignorage as a source of government revenue in our application.

16 The data were generously provided by Mr. Enzo Croce of the International Monetary Fund, and it is described in Croce, et.al. (2003). Our choice of countries was determined by the coverage of these data.
} 
Table 3: Estimation of the growth rate equation

\begin{tabular}{lccccc}
\hline & \multicolumn{2}{c}{ Coefficients estimates } & \multicolumn{2}{c}{ Summary statistics } \\
\cline { 2 - 6 } Countries & $\rho_{g}$ & $\rho_{g r}$ & $\bar{R}^{2}$ & $\operatorname{gbar}$ & $\operatorname{sig}(g)$ \\
\hline Argentina & $.85^{* *}$ & .11 & .85 & .0135 & .012 \\
Belgium & $.74^{* *}$ & 0 & .52 & .0058 & .0046 \\
Brazil & $.42^{* *}$ & $-.17^{* *}$ & .62 & .0067 & .0082 \\
Indonesia & $.74^{* *}$ & $-.02^{*}$ & .54 & .018 & .003 \\
Ireland & .99 & -.0054 & .91 & .012 & .0061 \\
Italy & .71 & -.12 & .68 & .005 & .0036 \\
Mexico & $.65^{* *}$ & $-.05^{* *}$ & .724 & .008 & .011 \\
Sweden & .91 & -.0166 & .88 & .0041 & .005 \\
Thailand & $.99^{* *}$ & $-.03^{* *}$ & .93 & .019 & .0076 \\
Turkey & $.85^{* *}$ & $-.06^{*}$ & .79 & .0098 & .001 \\
\hline
\end{tabular}

Note: -The end periods is 1997.4 while startıng period are as following: Argentına 1992.1;Belgium 1986.2; Braz1 1992.2;Indonesia 1991.1; Ireland 1983.1; Mexico 1990.4; Sweden 1983.1; Thailand 1983.1; Turkey 1984.4; gbar -stands for mean value; sig(g) stand for standard deviation; $(*)-5 \%$ level of significance; $(* *) 1 \%$ level of significance

\section{Real interest rate.}

Our measure of the real interest rate is $r_{t}=r_{t}^{d} \frac{b_{t-1}^{d}}{b_{t-1}}+r_{t}^{*} \frac{b_{t-1}^{*}}{b_{t-1}}$ where $r_{t}^{d}=\frac{\left(1+i_{t}^{d}\right)}{\left(1+\pi_{t}\right)}-1$ and $r_{t}^{*}=\frac{\left(1+i_{t}^{*}\right)\left(1+\xi_{t}\right)}{\left(1+\pi_{t}\right)}-1$. Since data on these variables are available for a longer period than for public debt we did not include any influence of the debt level on the interest rate, but estimated a simple $1^{\text {st }}$ order autoregressive process. The results are given in Table 4.

Table 4: Estimation of the interest rate equation

\begin{tabular}{lcccc}
\hline & Coefficients estimates & \multicolumn{2}{c}{ Summary statistics } \\
\cline { 2 - 5 } Countries & $\rho_{r}$ & $\bar{R}^{2}$ & rbar & sig(r) \\
\hline & $.65^{* *}$ & .41 & .12 & .19 \\
Argentina & $.40^{* *}$ & .15 & .0117 & .008 \\
Belgium & -.02 & .10 & .065 & .23 \\
Brazil & $5.25^{* *}$ & .96 & -.069 & .30 \\
Indonesia & $.53^{* *}$ & .28 & .019 & .011 \\
Ireland & $.54^{* *}$ & .28 & .014 & .005 \\
Italy & .17 & .10 & .034 & .10 \\
Mexico & $.28^{*}$ & .08 & .015 & .019 \\
Sweden & $1.06^{* *}$ & .56 & .024 & .038 \\
Thailand & $.53^{* *}$ & .27 & .021 & .053 \\
Turkey & & & \\
\hline
\end{tabular}

Note: -The end periods is 1997.4 while starting period are as following: Argentina 1992.1;Belgium 1986.2; Brazil 1992.2;Indonesia 1991.1; Ireland 1983.1; Mexico 1990.4; Sweden 1983.1; Thailand 1983.1; Turkey 1984.4; rbar-stands for mean value; sig(r) stand for standard deviation; $(*)-5 \%$ level of significance; $(* *) 1 \%$ level of significance 
The autoregressive interest rate model does not fit as well as the growth equation. As expected however, the real interest rates in emerging markets are generally significantly higher than those in developed ones. Their volatility, as measured by the standard deviation, is also much higher, $60 \%$ on a yearly basis while it is only $4 \%$ in developed countries.

\section{Primary deficit}

The primary deficit was modelled as a $1^{\text {st }}$ order autoregression with an additional effect due to the growth rate of real GDP:

$$
d_{t}=\bar{d}+\rho_{d} d_{t-1}+\rho_{d g} g_{t-1}+u_{d t}
$$

Table 4: Estimation of the primary deficit equation

\begin{tabular}{|c|c|c|c|c|c|}
\hline \multirow[b]{2}{*}{ Countries } & \multicolumn{2}{|c|}{ Coefficients estimates } & \multicolumn{2}{|c|}{ Summary statistics } & \multirow[b]{2}{*}{$\operatorname{sig}(d)$} \\
\hline & $\rho_{d}$ & $\rho_{d g}$ & $\bar{R}^{2}$ & $d b a r$ & \\
\hline Argentina & $.82^{* *}$ & -.018 & .85 & .0037 & .0014 \\
\hline Belgium & $.93^{* *}$ & 0 & .99 & -.002 & .003 \\
\hline Brazil & $.74^{* * *}$ &.- .076 & .68 & -.002 & .003 \\
\hline Indonesia & $1.064 * *$ & $.075^{*}$ & .89 & -.006 & .002 \\
\hline Ireland & $.94 * *$ & -.0289 & .98 & -.0059 & . 0084 \\
\hline Italy & $1.01 * *$ & -.009 & .99 & -.0002 & .0044 \\
\hline Mexico & $.90^{* * *}$ & -.011 & .91 & -.0085 & .004 \\
\hline Sweden & $.95^{* *}$ & $-.35^{* * *}$ & .98 & -.0005 & .012 \\
\hline Thailand & $.83^{* * *}$ & $-.20 * *$ & .99 & -.0047 & .007 \\
\hline Turkey & $.77^{* * *}$ & -.04 & .79 & .0098 & .001 \\
\hline
\end{tabular}

The primary deficit is clearly highly autoregressive in all countries, but the influence of the past growth rate is only significant in Sweden and Thailand. All the countries seem to run primarily surpluses on average, except for Argentina and Turkey. The highest volatilities of primary balances are recorded in Sweden and Ireland.

\section{III.1.2 Construction of the risk variable.}

Based on equation (13) and the estimated stochastic processes for the growth rates, interest rates, and the primary deficits we calculated density functions of debt/GDP ratios for all countries using Monte Carlo simulations. For illustrative purposes we present those of Mexico and Belgium after 16 quarters in Figure $8 .{ }^{17}$ Note that the distribution for Mexico has a significantly fatter right-hand tail than that of Belgium.

\footnotetext{
${ }^{17}$ In order to highlight the different shapes of the distributions, they have been centered around their respective means.
} 
Since our risk measure is based on the $95^{\text {th }}$ percentile of cumulative distribution function, Mexico will be recorded as riskier than Belgium.

Figure 8: Simulated distributions of Debt/GDP ratios

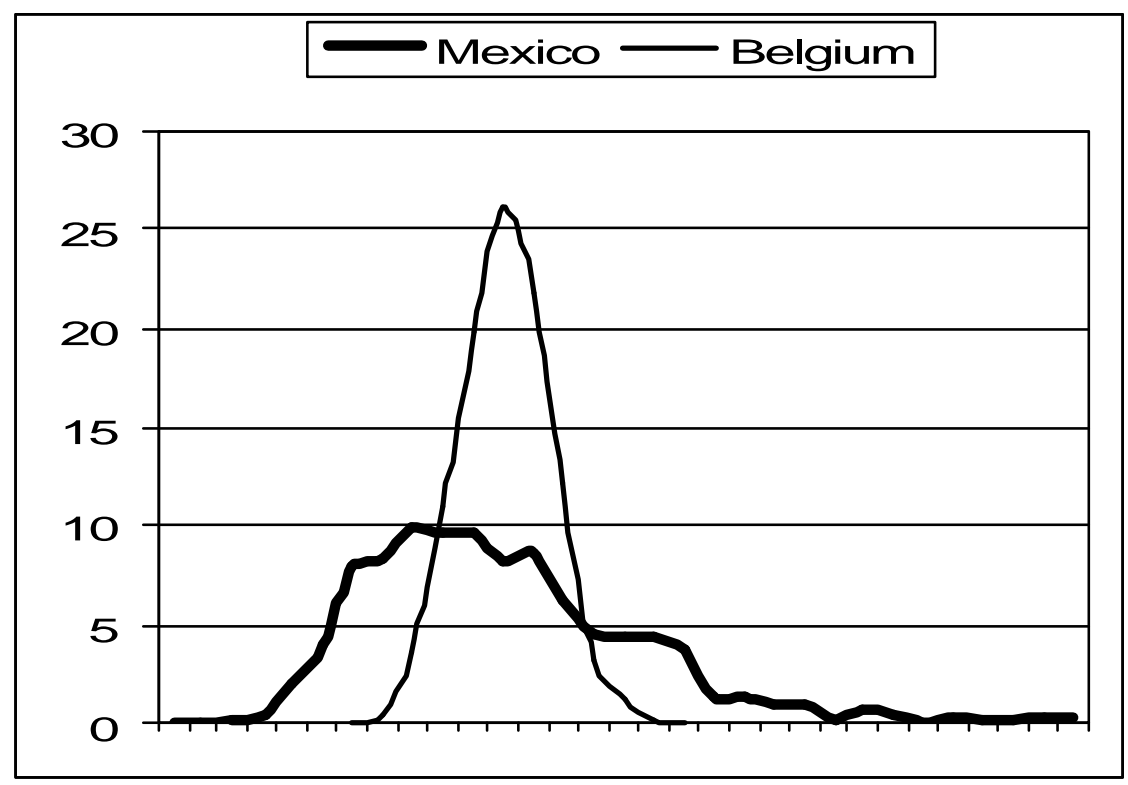

Formally the risk variable is defines as

$$
\operatorname{Risk}_{i, t}=1-\frac{\bar{b}_{i, t}}{b_{i, t}^{95, h}}
$$

where $b_{i, t}^{95, h}$ is the $95^{\text {th }}$ percentile of the distribution of the debt/GDP ratio for the country $i$ at the horizon $\mathrm{h}$, and $\overline{b_{i t}}$ is the mean of the debt to GDP ratio up to period $t$. By construction this variable is zero in the absence of shocks to the underlying variables since the Monte Carlo simulations are carried out under the assumption that the primary deficit is counterbalancing the difference between the growth rate and the real interest rate. For the cases of Belgium and Mexico shown in Figure 8 the calculated measures are $R_{\text {bel, } 97.4}=0.11$ and $R_{\text {mex }, 97.4}=0.65$, respectively.

To illustrate the potential importance of the risk variable as an explanation for the interest rate spreads, Figure shows the cross-country correlation between the two variables for the period 1997:4. The figure also shows that the aggregate risk measure has a stronger correlation with the spreads than the constituent components. This to us is an indication that the aggregation of the various volatilities into our overall risk measure is useful. 


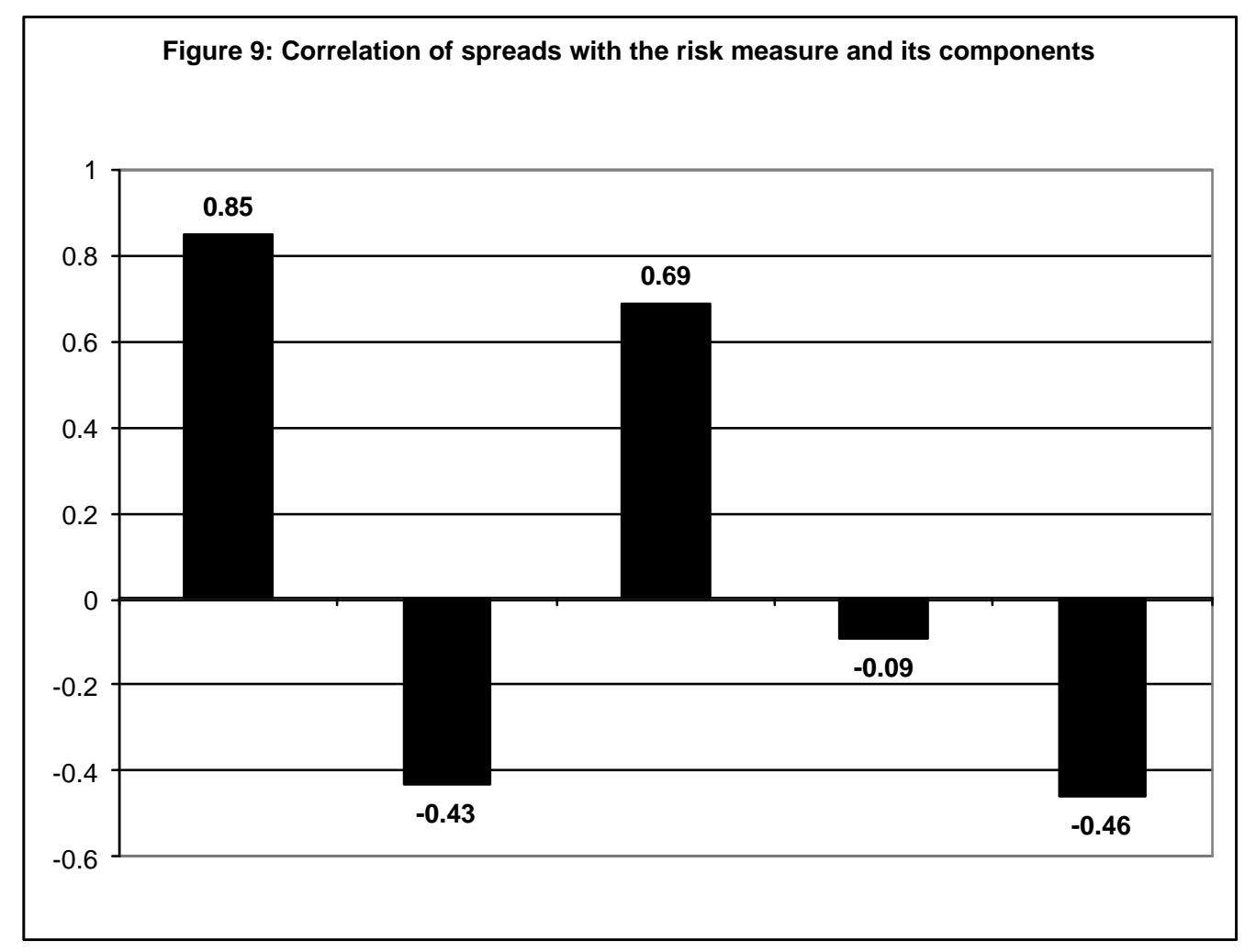

\section{III.2. Estimation method, data, and results}

For convenience we repeat the specification of the equation for the interest rate spread that we used in the estimation

$$
\begin{aligned}
& s_{i, t}=\alpha_{0}+\alpha_{1} \text { Risk }_{i, t-1}+\alpha_{2} \frac{D_{i, t-1}}{X_{i, t-1}}+\alpha_{3} \frac{R_{i t t-1}}{M_{i, t-1}}+\alpha_{4} \frac{C A_{i t-1}}{X_{i, t}}+\alpha_{5} \frac{F_{i t-1}}{Y_{i, t-1}}+\alpha_{6} i_{i, t-1}+ \\
& +\alpha_{7} D_{I, i}+\alpha_{8} D_{B, i}+\alpha_{9} D_{R, i}+\alpha_{10} \sigma(g)_{i, t-1}
\end{aligned}
$$

The risk variable and the standard deviation of real growth were constructed as described in the previous section. For the other variables data are taken from IMF-IFS statistics and Moody's-country credit risk statistical handbook. In order to avoid potential simultaneity problems all the independent variables influence the spreads with a oneperiod. ${ }^{18}$ The estimation method is pooled OLS.

Table 5 contains the main results. As can be seen the risk variable has the expected sign and is significant at $1 \%$ level. This result turns out to be robust to several

\footnotetext{
${ }^{18}$ In future work we intend to extend the sample to more countries in which case we will allow for fixed and/or random effects in the estimation. For the moment the only heterogeneity we allow is between emerging markets and developed economies.
} 
modifications in the specification as well as to a split in the sample between emerging markets and developed countries (Table 6).

Two alternative measures of riskiness, the dummy variable $D_{R}$ which indicates whether the country has defaulted on its debt at least once in last 20 years, and the volatility of real GDP growth, are both insignificant. This suggests that our combined measure of risk is a more appropriate indicator for the determinant of interest rate spreads.

Table 5: Estimation of the interest rate spread equation

\begin{tabular}{|c|c|c|c|c|c|c|c|c|c|}
\hline & \multicolumn{3}{|c|}{ Model I } & \multicolumn{3}{|c|}{ Model II } & \multicolumn{3}{|c|}{ Model III } \\
\hline Risk & \multicolumn{3}{|c|}{$\begin{array}{l}5.25 * * \\
(1.49)\end{array}$} & \multicolumn{3}{|c|}{$\begin{array}{l}4.7 * * \\
(1.31)\end{array}$} & \multicolumn{3}{|c|}{$\begin{array}{c}5.23 * * \\
(1.4)\end{array}$} \\
\hline$D / X$ & \multicolumn{3}{|c|}{$\begin{array}{c}.67 \\
(0.43)\end{array}$} & \multicolumn{3}{|c|}{$\begin{array}{l}.79 * \\
(0.44)\end{array}$} & \multicolumn{3}{|c|}{$\begin{array}{l}.73 \\
(.46)\end{array}$} \\
\hline$R / M$ & \multicolumn{3}{|c|}{$\begin{array}{c}-5.83^{* *} \\
(1.91)\end{array}$} & \multicolumn{3}{|c|}{$\begin{array}{l}-5.23 * \\
(2.11)\end{array}$} & \multicolumn{3}{|c|}{$\begin{array}{l}-6.54 * \\
(3.32)\end{array}$} \\
\hline$C A / X$ & \multicolumn{3}{|c|}{$\begin{array}{l}-5.24 * \\
(2.32)\end{array}$} & \multicolumn{3}{|c|}{$\begin{array}{l}-4.21^{*} \\
(1.94)\end{array}$} & \multicolumn{3}{|c|}{$\begin{array}{l}-5.35^{*} \\
(2.41)\end{array}$} \\
\hline$F / Y$ & \multicolumn{3}{|c|}{$\begin{array}{l}-.0136 \\
(.072)\end{array}$} & \multicolumn{3}{|c|}{$\begin{array}{l}-.021 \\
(.083)\end{array}$} & \multicolumn{3}{|c|}{$\begin{array}{c}-.0437 \\
(.08)\end{array}$} \\
\hline$i$ & \multicolumn{3}{|c|}{$\begin{array}{c}-.4925 * * \\
(.25)\end{array}$} & \multicolumn{3}{|c|}{$\begin{array}{l}-.49^{*} \\
(.21)\end{array}$} & \multicolumn{3}{|c|}{$\begin{array}{l}-.49^{* * *} \\
(.16)\end{array}$} \\
\hline$D_{I}$ & \multicolumn{3}{|c|}{$\begin{array}{c}-2.27 * \\
(1.13)\end{array}$} & \multicolumn{3}{|c|}{$\begin{array}{c}-2.19^{* *} \\
(.90)\end{array}$} & \multicolumn{3}{|c|}{$\begin{array}{l}-1.89 \\
(1.36)\end{array}$} \\
\hline$D_{b r a d y}$ & \multicolumn{3}{|c|}{$\begin{array}{c}-5.14^{* *} \\
(1.01)\end{array}$} & \multicolumn{3}{|c|}{$\begin{array}{c}-4.97^{* *} \\
(.68)\end{array}$} & \multicolumn{3}{|c|}{$\begin{array}{c}-5.2 * * \\
(1.27)\end{array}$} \\
\hline$D_{R}$ & & & & & $\begin{array}{l}-.09 \\
(.78)\end{array}$ & & & $\begin{array}{l}-.36 \\
(1.05)\end{array}$ & \\
\hline \multirow[t]{4}{*}{$\sigma(g)$} & \multicolumn{3}{|c|}{$\begin{array}{l}.858 \\
(.98)\end{array}$} & & & & \multicolumn{3}{|c|}{$\begin{array}{c}1.06 \\
(1.06)\end{array}$} \\
\hline & \multicolumn{3}{|c|}{ Summary Statistics } & \multicolumn{3}{|c|}{ Summary Statistics } & \multicolumn{3}{|c|}{ Summary Statistics } \\
\hline & $\bar{R}^{2}$ & S.E & D-W & $\bar{R}^{2}$ & S.E & D-W & $\bar{R}^{2}$ & S.E & D-W \\
\hline & 0.76 & 1.39 & 1.33 & .75 & 1.4 & 1.35 & .76 & 1.39 & 1.33 \\
\hline
\end{tabular}

Reserves to imports and current account balance have the expected negative influence on sovereign spreads and they are highly significant. The impact of the debt/export ratio is not robust, however, as the sign changes depending on the specification and the significance is generally low. It appears that the risk associated with large potential increases in debt ratios is more important for interest rate determination than the debt level itself. ${ }^{19}$

\footnotetext{
${ }^{19}$ This is consistent with Reinhart, Rogoff, and Savastano(2003) who argue that the critical value of the debt ratio varies across countries according to their history of debt service.
} 
The US interest rate seems to have a negative influence on bond spreads. One rationale proposed by Ferrucci(2003) is that investors are more interested on the slope of term structure. The steeper the term structure, the higher the long term bond yield, the lower credit spreads.

Brady restructuring dummy is found to be highly significant and appears to have the effect of lowing the spread, contrary to the results in Cline and Barnes, op. cit.. This could be an indication that participation in a Brady restructuring scheme acts as a sign of good housekeeping thereby lowering the cost of external finance.

When we split the sample into one group of emerging markets and one group with developed countries, the significance of our risk measure remains as shown in Table 6. Noteworthy changes in the results are that for developed countries the coefficient on the current account becomes positive but insignificant while that on the fiscal balance turns out to be significant. International interest rates do plays an important role for emerging market bond spreads, while they do not seem to matter for the developed countries.

Table 6: Estimation of the interest rate spread equation

\begin{tabular}{|c|c|c|c|c|c|c|}
\hline \multirow[b]{2}{*}{ Risk } & \multicolumn{3}{|c|}{ Emerging markets } & \multicolumn{3}{|c|}{ Developed countries } \\
\hline & \multicolumn{3}{|c|}{$\begin{array}{l}4.88^{*} \\
(1.85)\end{array}$} & \multicolumn{3}{|c|}{$\begin{array}{c}3.15^{* *} \\
(1.1)\end{array}$} \\
\hline$D / X$ & \multicolumn{3}{|c|}{$\begin{array}{l}1.07 \\
(.68)\end{array}$} & \multicolumn{3}{|c|}{$\begin{array}{l}-1^{*} \\
(.38)\end{array}$} \\
\hline$R / M$ & \multicolumn{3}{|c|}{$\begin{array}{l}-9.33 \\
(5.75)\end{array}$} & \multicolumn{3}{|c|}{$\begin{array}{c}-2.8 * * \\
(.87)\end{array}$} \\
\hline$C A / X$ & \multicolumn{3}{|c|}{$\begin{array}{l}-5.91 \\
(3.8)\end{array}$} & \multicolumn{3}{|c|}{$\begin{array}{c}1.8 \\
(1.90)\end{array}$} \\
\hline$F / Y$ & \multicolumn{3}{|c|}{$\begin{array}{l}-.076 \\
(.14)\end{array}$} & \multicolumn{3}{|c|}{$\begin{array}{l}.11^{* * *} \\
(.032)\end{array}$} \\
\hline$i$ & \multicolumn{3}{|c|}{$\begin{array}{c}-.76^{* *} \\
(.27)\end{array}$} & \multicolumn{3}{|c|}{$\begin{array}{c}-.02 \\
(.038)\end{array}$} \\
\hline$D_{\text {Brady }}$ & \multicolumn{3}{|c|}{$\begin{array}{c}-5.78^{* * *} \\
(1.86)\end{array}$} & & & \\
\hline$D_{R}$ & \multicolumn{3}{|c|}{$\begin{array}{c}.95 \\
(1.61)\end{array}$} & & & \\
\hline \multirow[t]{4}{*}{$\sigma(g)$} & \multicolumn{3}{|c|}{$\begin{array}{c}-2.2 \\
(2.03)\end{array}$} & \multicolumn{3}{|c|}{$\begin{array}{c}-.97 * \\
(.37)\end{array}$} \\
\hline & \multicolumn{3}{|c|}{ Summary Statistics } & \multicolumn{3}{|c|}{ Summary Statistics } \\
\hline & $\bar{R}^{2}$ & S.E & D-W & $\bar{R}^{2}$ & S.E & D-W \\
\hline & .45 & 2.01 & 1.56 & .42 & .15 & 1.57 \\
\hline
\end{tabular}




\section{Extensions.}

We have proposed a measure of risk associated with a sovereign debtor built on an aggregation of parameters describing the volatility of the fundamental variables determining the dynamics of the country's debt/GDP ratio. The measure was shown to be a powerful explanatory variable in a regression equation explaining the spread of interest rates on sovereign debt over US Treasuries.

Additional use of the risk measure can be imagined. For example, it would be interesting to investigate if it has explanatory power in models designed to predict sovereign default probabilities, or in models that attempt to predict sudden stops in capital flows to emerging markets and associated currency pressures.

The construction of the measure itself may be elaborated in several directions. The exchange rate should be explicitly included in the analysis when foreign-currency denominated debt is important. This would introduce the possibility of valuation effects of the existing external debt as a result of exchange rate changes. Other stochastic processes for the fundamentals could also be explored, for example regime switching models for the growth rate of real output, or jump processes for the exchange rate.

It would finally be useful to extend the data sample studied in this paper both to more countries and to other time periods. 


\section{References}

Agenor, P.R(2001) "Fiscal Policy, Public Debt Sustainability and Solvency" in Macroeconomic Management for Financial Stability and Poverty Reduction Conference, San Paolo, Brazil

Ahmed, Sh. and Rogers, J. (1995) " Governments budget deficits and trade deficits are present value constraints satisfied in long-term data?" Journal of Monetary Economics 36 351374.

Barnhill, Th. Jr.\& Kopits G. (2003), "Assessing fiscal sustainability under uncertainty" IMF Working Paper, WP/03/79 (Washington: International Monetary Fund)

Bartolini, L. and Cottarelli, C (1994) "Government Ponzi games and the sustainability of public deficit under uncertainty", Ricerche economiche 48, 1-22.

Beck, R.(2001) Do country fundamentals explain emerging market bond spreads" CFS Working Paper No. 2001/02.(Frankfurt am Main: Center for Financial Studies) .

Catao,L \& Kapur, S (2004), "Missing link: Volatility and the debt intolerance paradox", IMF Working Paper, WP/04/51. (Washington: International Monetary Fund)

Cline W,. and Barnes K. (1997) "Spreads and Risk in Emerging Markets Lending" IIF Research Papers No. 97.1(Washington: Institute of International Finance)

Croce, E. \& Hugo Juan Ramon, V.(2003),"Assessing fiscal sustainability: a cross country comparison", IMF Working Paper WP/03/145. (Washington: International Monetary Fund)

Cuddington J.(1997) "Analysing the sustainability of fiscal deficits in developing countries" World Bank Policy Research Working Paper. No. 1784(Washington: World Bank)

Dell'Ariccia, G Goedde,I and Zettelmeyer,J.(2002), "Moral hazard in international crises lending: a test" IMF Working paper WP/02/181 (Washington: International Monetary Fund)

Detragiache, E. and A. Spilimbergo (2001) "Crises and Liquidity: Evidence and interpretation", IMF working paper WP/01/2, (Washington: International Monetary Fund)

Eaton, J and Gersovitz, M.(1981) "Debt with potential repudiation: the oretical and empirical analysis" Review of Economic Studies, No. 48, pages 289-309

Edwards, S.(1986) "The pricing of bonds and bank loans in international markets", European Economic Review 30 pp.565-589

Eichengreen, B. and Mody, A. (1998) "What explains the changing spreads on emerging market debt?" NBER Working paper No. 6408 
Ferrucci, G. (2003) "Empirical determinants of emerging market economies' sovereign bond spreads" Bank of England Working Papers, No. 205.

Gavin,M and Perotti,R.(1997) "Fiscal policy in Latin America" NBER Macroeconomics Annual Vol.12.

Goldfajn, Ilan (2002) "Are there reasons to doubt fiscal sustainability in Brazil ? " Banco Central do Brazil Technical Notes, Number 25

Goldman Sachs(2000) "Introducing GS_ESS: A new framework for assessing fair value in emerging market hard currency debt", Goldman Sachs Global Economic Paper No. 45

Goldstein, M(2003) "Debt Sustainability, Brazil and IMF", IIE working papers No. 03-1. (Washington: Institute for International Economics).

Hakkio, C.S. and M. Rush (1991). "Is the budget deficit too large?" Economic Inquiry 29, 429445

Hamilton and Flavin (1986) "On the limitation of government borrowing: a framework for empirical testing", American Economic Review 76, 808-819.

Henning, B. (1995). "The sustainability of budget deficit in a stochastic economy", Journal of Money, Credit and Banking 27, 257-271

IMF(2002), "Assessing sustainability" Policy Development and Review Department. (Washington: International Monetary Fund)

IMF(2003), "Sustainability Assessments-Review of Application and Methodological Refinements" Policy Development and Review Department. (Washington: International Monetary Fund).

Jorion,P.(2001) "VAR Value at Risk: The New Benchmark for Managing Financial Risk", McGraw-Hill.

Kamin,S. and von Kleist,K(1999), " The evolution and determinants of emerging market credits spreads in the 1990's" BIS Working Paper 68 (Basel: Bank for International Settlement)

Kremers, J. (1989) " U.S. Federal indebtedness and the conduct of fiscal policy", Journal of Monetary Economics XXIII, 219-238.

Min, H.G.(1998) "Determinants of Emerging market Bond spreads: Do economic fundamentals matter?" World Bank Policy Research Working Paper 1899 (Washington: World Bank).

Moody's(2003), "Moody's Country Credit Statistical Handbook", Global Credit Research, Investor's Service. 
Peter, M(2002) " Estimating Default Probabilities of Emerging Market Sovereigns: A New Look at a Not-So-New Literature", HEI Working Paper No. 06/2002.(Geneva: Graduate Institute for International Studies).

Reinhart, C., Rogoff,,K and Savastano.,M. "Debt Intolerance" NBER Working Paper No. 9908

Trehan, B. and Walsh, C.E.(1991), "Testing inter temporal Budget Constraint: Theory and Applications to US Federal Budget and Current Account Deficits" Journal of Money, Credit and Banking, 23(2), 206-223.

Uctum, M and Wickens, M (1996) "Debt and deficit ceilings, and sustainability of fiscal policy: an inter temporal analysis". Federal Reserve Bank of New York, Research Paper No. 9615.

Wilcox, D.W(1989). "The sustainability of government deficits: Implications of the present value borrowing constraint," Journal of Money, Credit and Banking 21(3), 291-306. 